АРХЕОЛОГИЯ КАЗАХСТАНА № 2 (8) 2020

УДК 902/904

https://doi.org/10.52967/akz2020.2.8.123.144

\title{
ПАМЯТЬ О МОЕМ УЧИТЕЛЕ - АЛЕКСЕЕ ПАВЛОВИЧЕ ОКЛАДНИКОВЕ
}

\author{
(C) 2020 г. Ж. Таймагамбетов
}

В феврале 2020 г. исполнилось ровно 40 лет, как я впервые переступил порог Института истории, филологии и философии Сибирского отделения АН СССР, ныне самостоятельный Институт археологии и этнографии СО РАН. Тогда и познакомился с крупнейшим ученым, легендой археологии, этнографии и истории народов Сибири, Северной, Центральной и Восточной Азии, Героем Социалистического Труда, Алексеем Павловичем Окладниковым (1908-1981) (рис. 1). Чуть больше года мы общались с ним, хотя и изредка. Но этого хватило, чтобы он надолго оставил яркий след в моей жизни и памяти. А сумасшедшее время стремительно летит, и уже 39 лет прошло, как навсегда ушел мой учитель, ушел в вечную экспедицию. Но я все помню о нем, все до мельчайших подробностей, словно расстались мы недавно. Алексея Павловича невозможно забыть, прежде всего, как человека, ученого. Как все это начиналось и было... Попробую совершить небольшой экскурс и восстановить события прошлого.

Ключевые слова: археология, А.П. Окладников, Институт археологии и этнографии СО РАН, каменный век, палеолит, воспоминания

В археологию я пришел случайно. У меня и мысли не было посвятить себя науке. На 1 курсе учебы в вузе, преподаватель дисциплины «Основы археологии» доцент А. М. Оразбаев, в «наказание» за несвоевременную сдачу контрольной работы дал мне тему курсовой работы «Палеолит Казахстана», когда остальные сокурсники имели право выбора темы по желанию. После занятий я вечерами засиживался в библиотеке, пытаясь найти необходимую литературу. Проблема палеолита так увлекла меня, что я становился неоднократным участником и призером региональных и всесоюзных студенческих конференций в Алма-Ате, Ашхабаде, Душанбе, Москве, Самарканде, Ташкенте. К третьему курсу моим руководителем стал кандидат исторических наук Хасан Алпысбаевич Алпысбаев, ученик профессора Павла Иосифовича Борисковского. Работая с ним в археологической экспедиции на Иртыше, я дал слово, что не оставлю археологию и не променяю «палеолит» на другие периоды археологии. За год до моего окончания университета, он покинул этот мир.

В 1979 году я окончил истфак КазГУ, защитил дипломную работу «Палеолит Казахстана» на «отлично». До защиты я получил заманчивое предложение поступить на службу в органы МВД, с получением квартиры. Однако, после прохождения трехмесячных офицерских сборов, я остался верен слову, данному Х. А. Алпысбаеву и комиссией вуза был направлен на работу в отдел археологии Института истории, археологии и этнографии им. Ч.Ч. Валиханова АН КазССР. 


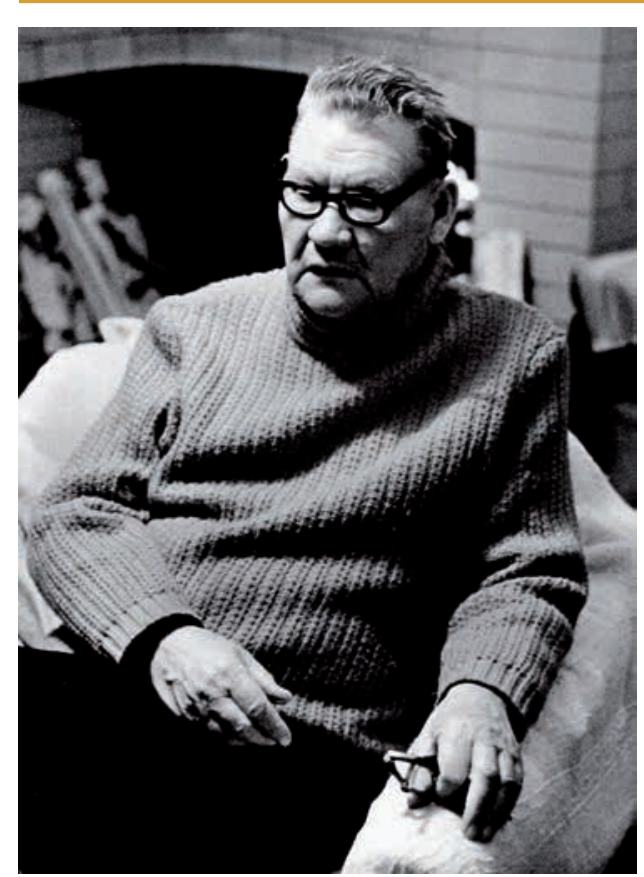

Рис. 1. Алексей Павлович Окладников. Одна из последних фотографий. 19812. Фото В. Новикова

Fig. 1. Alexey P. Okladnikov. One of the last photos. 1981. Photo by V. Novikov

Проработав два месяца в Институте в должности старшего лаборанта, я получил письмо из Новосибирска, от самого Алексея Павловича Окладникова с предложением приехать к нему на трехгодичную стажировку. Как он узнал обо мне? Оказывается, благодаря руководителю отдела археологии К. А. Акишеву, за подписью директора Института А. Н. Нусупбекова, академику А. П. Окладникову было направлено письмо в Новосибирск о возможности прохождения моей стажировки в Институте истории, филологии и философии Сибирского отделения АН СССР (рис. 2).

Радости моей не было предела. Не откладывая дела на «потом», благо, что у меня ничего не было, ни квартиры, ни прописки в городе, не состоял на воинском учете, я быстро переправил семью в г. Волгоград, где проживали родители супруги, а сам отправился в Новосибирск.

И вот, 6 февраля 1980 года, я сошел с трапа самолета рейса № 6551 Душанбе-Алма-Ата-Новосибирск и прямиком, на такси, поехал в Академгородок. Была солнечная погода, горы снега и сильный мороз. Ехать от аэропорта пришлось долго. Наконец, я стою у порога Института, что на втором этаже в здании Президиума АН СО АН СССР. Секретарь в приемной, Нелли Васильевна Ворошилова, это я потом узнал, сказала: «Алексей Павлович будет к 16.00. Подъедет он на серой "Волге", с тростью в руке, рядом с ним будет его помощник, огромный и с большой бородой. Зовут его Александр Киррилович Конопацкий». Это я ее расспрашивал как выглядит академик и его помощник. Поскольку я никого не знал, да и не знал куда идти, то я пошел в сквер через дорогу, что напротив главного входа в здание Президиума и сел на лавочку, ожидая Алексея Павловича. Я вглядывался во все автомобили, которые останавливались у главного входа. Основательно замерз, когда появилась очередная машина и, к моему счастью, из нее вышли двое - человек с тростью и сопровождающий богатырь с большой бородой. Я быстро поднялся и побежал к зданию. Дежуривший у входа милиционер, которому я ранее представлялся, пропустил меня, подтвердив мой вопрос: «Да, это академик Окладников» (рис. 3).

И вот я в приемной директора, где ждут аудиенции несколько человек. Сердце стучало, в голове мысль: «Как меня примет и встретит Алексей Павлович? Вдруг откажется принять на стажировку? ... Мало ли что... Ведь у себя на родине я часто был в 
таймагамбетов Ж. Память о моем учителе - Алексее Павловиче Окладникове

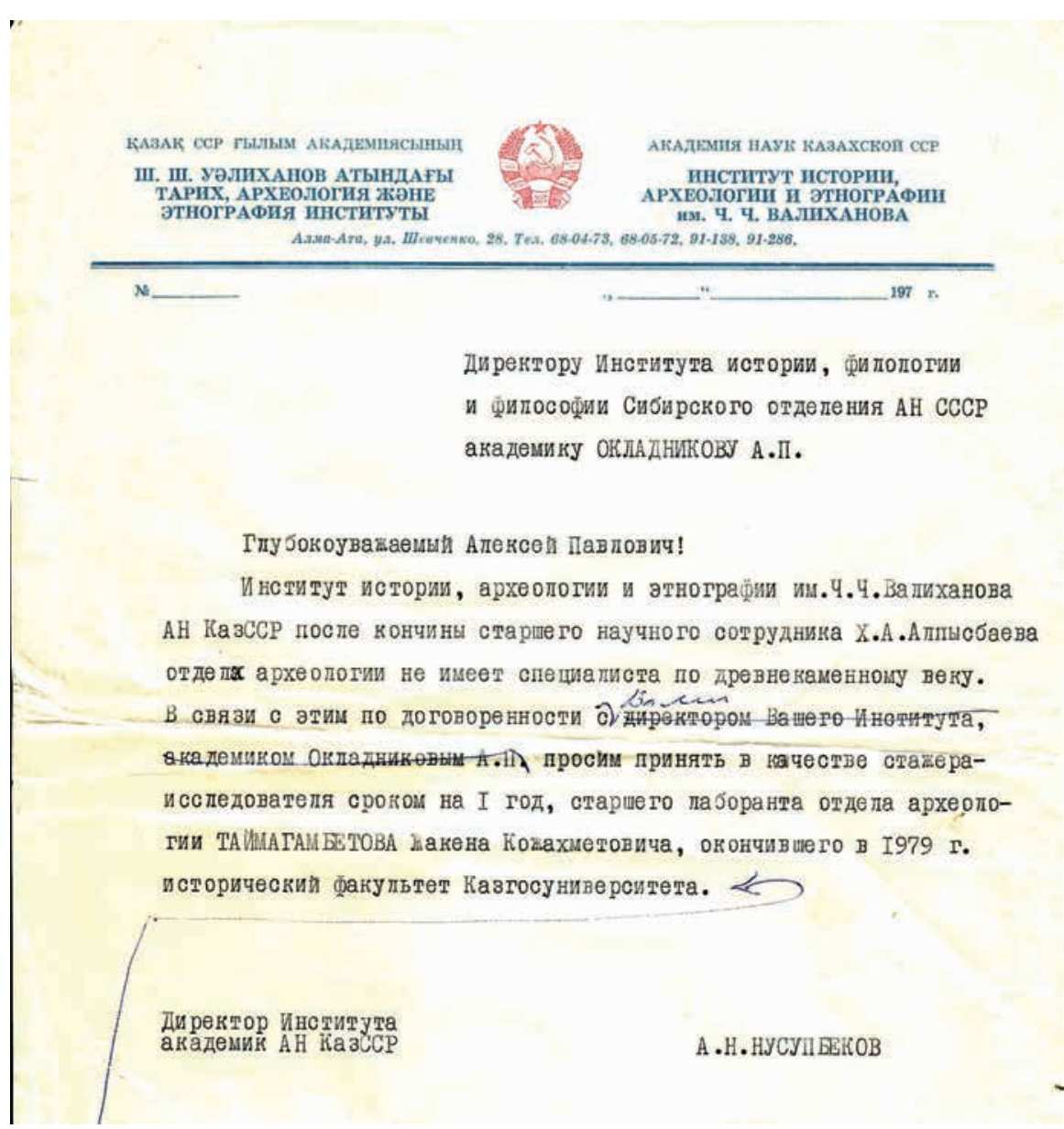

Рис. 2. Черновик письма А. Н. Нусупбекова, адресованного А. П. Окладникову. 1979 г.

Fig. 2. Draft of the letter of A. N. Nusupbekov addressed to A. P. Okladnikov. 1979.

положении, когда часами просиживал в ожидании приема чиновникамибюрократами, чтобы получить разрешение на прописку в городе и получал отказ. А что, если...». Но, чудо! Нелли Васильевна, вне очереди, разрешила мне пройти к нему в кабинет. Постучавшись, я зашел и увидел за столом человека с ручкой, увлеченно склонившего голову над бумагами и делающего пометки. Это был Алексей Павлович. С порога, по-военному, я отчеканил: «Здравствуйте, Алексей Павлович! Таймагамбетов Жакен из Алма-Аты прибыл в Ваше распоряжение...». Он удивленно посмотрел на меня и, несмотря на занятость, возраст и занимаемую должность, встал с улыбкой из-за стола, подошел и крепко, по-отечески, обнял меня. «С приездом, я ждал Вас, присаживайтесь..., как добрались, рассказывайте..., где остановились и т.д.». Сразу улетучились все мои сомнения, я знал, что в дальнейшем у меня все будет хорошо, такой человек не оставит меня наедине с проблемами. Я запомнил его добрую и мягкую улыбку, уставший, любознательный взгляд. С этой минуты мне казалось, что знаю Алексея Павловича давно. Я словно встретился со своим отцом, который рано 


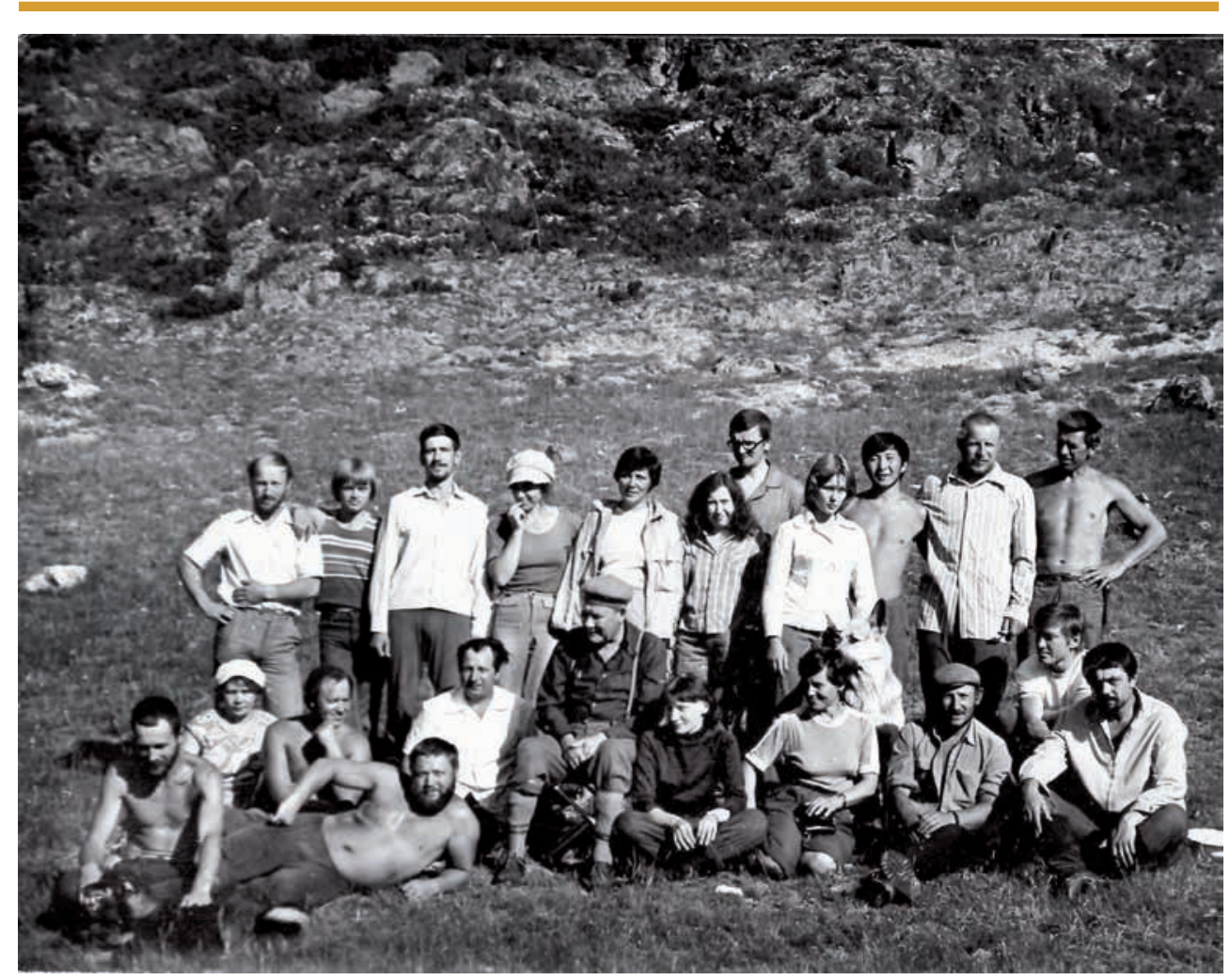

Рис. 3. Состав Северо-Азиатской археологической экспедиции. В иентре А. П. Окладников. 1980 г. Фото А. Глотова

Fig. 3. Team of the North Asian Archaeological Expedition. A. P. Okladnikov in the center. 1980. Photo by A. Glotov

ушел из жизни. Не злоупотребляя его расположением ко мне, коротко рассказал о себе, семье. Даже осмелился напомнить ему, что в приемной его ждут люди, а мне надо идти, пока светло и искать ночлег. Тогда он вызвал своего заместителя по общим вопросам Баринова Вадима Ивановича и распорядился, чтобы меня на некоторое время разместили в гостинице «Золотая долина». Прощаясь, сказал: «Отдохните, а завтра, после обеда приходите, поговорим о работе». Вот и все его слова при первой встрече, а сколько было в нем обнадеживающего и значимого для меня!

У себя в кабинете Вадим Иванович позвонил директору гостиницы «Золотая долина», подготовил и дал мне сопроводительное письмо, машину. Несмотря на отсутствие свободных номеров, мне нашли место, и я без проблем устроился.

Из окна гостиницы незнакомого мне городка я увидел много снега, густой лес до самого горизонта и клубы светлого дыма, тянущиеся ввысь из труб промышленных предприятий. Но меня не пугали морозы и холод, мне не было одиноко, у меня была надежная защита и человек - сам Алексей Павлович Окладников.

Так состоялась моя первая встреча с человеком-легендой, о котором я слышал студентом на лекциях. Долго не мог заснуть, все думал об Алексее Павловиче. Прежде всего, меня удивила его простота, доброта 
и скромность во всем. Нет никакого высокомерия, превосходства перед кем-то и общение со мной на «Вы». Впервые за многие месяцы мне хорошо спалось в гостинице. Так началась моя сибирская эпопея, длящаяся уже 40 лет. И я очень дорожу этой дружбой.

На следующее утро, подкрепившись завтраком и чаем из огромного самовара, который находился прямо в фойе гостиницы, я в назначенное время был у Алексея Павловича. Он тут же вызвал двух молодых сотрудников и, представив меня, познакомил с ними. Это были Валерий Трофимович Петрин и Юрий Павлович Холюшкин. «Берите его к себе в команду, покажите коллекции камней, подсказывайте и работайте вместе», - сказал Алексей Павлович на ходу, куда-то торопясь. Я с новоявленными коллегами поднялся на чердак, где находились и хранились многочисленные археологические коллеции в коробках разных размеров. Юрий Павлович по пути где-то «потерялся», а Валерий Трофимович познакомил меня с археологами - Ю. Гричаном, Д. Березиным, С. Глинским, В. Буриловым, которые сидели между стеллажами с коробками и что-то горячо обсуждали. Узнав, что я из Казахстана, Сергей Глинский обратился с просьбой, если будет возможность достать для него книгу Олжаса Сулейменова «Аз и Я». Позже я выполнил его просьбу.

Валерий Трофимович показывал и открывал коробки с коллекциями каменных изделий с палеолитических стоянок Алтая и Сибири и давал им краткую характеристику, объяснял мне термины и назначение артефактов. Временами он возвращался к своей работе, которая заключалась в обработке коллекции материалов из открытых им новых памятников на Урале и написании отчета для сдачи в Полевой комитет. Я всячески старался быть полезным ему, помогал мыть находки, шифровать и рисовать камни, а заодно знакомился с коллекциями и публикациями по палеолиту.

Так проходили дни. С Алексеем Павловичем встречались, когда он вызывал к себе Валерия Трофимовича по работе, иногда и меня вместе с ним, он интересовался, коллекции каких памятников я успел посмотреть, что я читаю и т.д. Я отвечал, что Валерий Трофимович оказывает мне посильную помощь, да и другие археологи всегда приветливы ко мне, и каждый из них знакомит меня с результатами своей экспедиции. Алексей Павлович был рад такому ответу.

Через месяц проживания в гостинице деньги у меня начали иссякать, выручил Валерий Трофимович. Он жил в трехместной комнате общежития, на «Ученых, 8», где поговорил с проживающими ребятами, и никто не возражал, чтобы я приходил на ночлег. Я устраивался спать на двери, которую нашел Валерий Трофимович. Один конец двери был на столе, а другой чуть пониже на стуле. Поэтому я рано приходил на работу, когда все спали, и уходил с работы к середине ночи, когда жильцы в комнате укладывались спать. Так было в течение двух месяцев, до моего отъезда в экспедицию.

Круг моего знакомства с археологами расширился во время переезда отделов Института из здания напротив Президиума в новое четырехэтажное, которое сейчас занимает Институт археологии и этнографии СО РАН. Утром мы начинали работать с большим участием сотрудников, а к концу дня оставались втроем - Валерий Тро- 
фимович, Витя Эрлих и я. Сотрудники обустраивали только свой отдел и уходили. Мы помогали отделам, там, где мало было мужчин - этнографам, бухгалтерии, канцелярии, отделу кадров и т.д. Итак, на протяжении недели, мы выносили из здания и грузили мебель на автомашину, везли, затем разгружали и разносили по комнатам на этажах. Вдвоем с Валерием Трофимовичем собирали новую мебель для Алексея Павловича на втором этаже, где сейчас находится кабинет академика Анатолия Пантелеевича Деревянко, кресла и столы в зале Ученого совета. Кроме того, мы носили новую мебель в упаковке на чердак здания, в 108-ю угловую комнату, и там же собирали. Впоследствии в этой комнате сидели и работали Валерий Трофимович, Александр Киррилович, Оксана Реймерс и я. Работа без ограничения во времени сблизила нас с Валерием Трофимовичем Петриным, мы подружились и до конца его жизни мы остались верными этой дружбе.

Ранней весной 1980 г. в академгородке проходила этнографическая выставка «Искусство Океании», организованная художником, этническим русским из Франции Н. Н. Мишутушкиным. Пока ждали высокопоставленных лиц из Москвы, Президиума СО АН СССР и Новосибирского обкома партии, Алексей Павлович рассказал мне и Руслану Сергеевичу Васильевскому, что когда Н. Н. Мишутушкин проходил службу в Новой Каледонии, то собирал этнографические экспонаты, а после заинтересовался искусством коренных народов Океании. Так и появилась в академгородке эта выставка. Выставку посетили секретарь обкома А. П. Филатов, президент CO АН СССР В. А. Коптюг и председатель по науке и технике СССР 128
Г. И. Марчук. Алексей Павлович подозвал меня и сказал в присутствии всех: «Гурий Иванович, знакомьтесь, это мой аспирант из Казахстана Жакен Таймагамбетов». Мы пожали руки. Я тихо сказал: «Алексей Павлович, я же стажер-исследователь, а не аспирант...». На что Алексей Павлович ответил: «Запомните, будете аспирантом, а личное знакомство это 50 процентов вашей проделанной работы». Все рассмеялись. Как он был прав, впоследствии, в трудных ситуациях не раз меня выручало это «личное знакомство».

Так пролетели три месяца моей «научной стажировки». С Алексеем Павловичем виделись редко, он постоянно был в разъездах. Но, благодаря ему, я был сразу же прописан в Академгородке и поставлен на воинский учет в Советском районе, чего не мог добиться в Алма-Ате. С этим делом в то время было очень строго, могли привлечь к ответственности. Я часто общался с помощником Алексея Павловича Александром Кирриловичем, который по-дружески относился ко мне и всячески поддерживал советами.

Однажды через него Алексей Павлович позвал меня к себе домой, в коттедж на Золотодолинской. Когда я подошел в назначенное время, он сидел на стульчике у крыльца. После недолгого разговора провел меня в комнату и познакомил со своей супругой, Верой Дмитриевной Запорожской. За чаем Алексей Павлович предложил мне после майских праздников поехать с ним в Горный Алтай и принять участие в Северо-Азиатской археологической экспедиции. Я с удовольствием принял его предложение. Временами нас прерывали телефонные звонки, его искали, он был кому- 
то нужен. Даже дома не было покоя ему. Но строгая Вера Дмитриевна не ко всем приглашала Алексея Павловича. По телефону кому-то давал распоряжения, с кем-то обсуждал план на ближайшее время, кого-то просил обратиться к заместителю и т.д. Он был постоянно в работе и в движении. Освободившись от очередного разговора, Алексей Павлович проводил меня в библиотеку, где на металлических стеллажах в несколько рядов находилось очень много книг, чтобы я посмотрел и подобрал специальную литературу для чтения. После осмотра я выбрал две книги по проблеме техники леваллуа. На прощание он подарил мне еще стопку книг по палеолиту и красивую японскую вазу, украшенную перламутрами. Одна из книг маленького размера «Олень золотые рога» привлекла мое внимание и я сразу развернул ее. Она была с надписью «Проф. О. Латтимору в знак глубокого уважения и дружбы. А. Окладников. Улан-Батор. 17.VIII.64.». Я показал ее Алексею Павловичу, но он вернул мне со словами: «Столько времени прошло, ему она уже не нужна, я другую ему подарил. Да и живет он в другой стране. Возьми ее себе, Жакенчик (так ласково он называл меня), прочти...». Поблагодарив за подарок, окрыленный возможностью поехать с ним в экспедицию, я пришел в общежитие и поделился новостью со своим другом «Трофимычем», так уважительно я стал его называть. Он обрадовался, оказалось мы вместе едем в одну экспедицию. За день до выезда, получив экспедиционное оборудование от заведующей складом Галины Ивановны, мы заранее погрузили их в две автомашины ГАЗ-66.
Наступило 14 мая 1980 года. Мой первый выезд в экспедицию с масштабно-интригующим названием «Северо-Азиатская археологическая экспедиция» (рис. 4). Мне казалось, что другие экспедиции ничего не значат. Ведь эту экспедицию возглавил сам АП, так за спиной уважительно называли его археологи и другие сотрудники Института. Ранним утром мы выехали на Алтай, а по пути заехали в Барнаул, где нас встретил Юрий Федорович Кирюшин, тоже археолог (впоследствии, мы станем друзьями с ним и его семьей), давний друг Трофимыча. Пообщавшись, мы двинулись к месту назначения. Мне было интересно, все необычно, горы, тайга, высокие деревья, сосны, ели, пихта, обилие рек и ручьев, все это отсутствовало у нас, в степи, где я родился.

На следующий день мы прибыли к месту назначения. Разбили лагерь и приступили к раскопкам палеолитической стоянки Кара-Тенеш, которая находилась в Шебалинском районе. В день прибытия приехали к Алексею Павловичу местные руководители и в знак уважения к нему преподнесли двух баранов. Алексей Павлович поручил мне разделать одного из них. Когда я повалил и связал ноги барана и собирался перерезать горло животному, молча и удивленно наблюдавшие за моими действиями алтайцы, мягко оттолкнув меня в сторону, сами разделали тушу. Я впервые увидел как алтайцы, не спуская кровь, разделывают барана и делают кровяную колбасу.

Через несколько дней Алексей Павлович дал нам задание, а сам вместе с Александром Кирриловичем уехал в разведку, на поиски новых памятников. Начальником отряда 


\section{ҚАЗАҚСТАН АРХЕОЛОГИЯСЫ №v 2 (8) 2020}

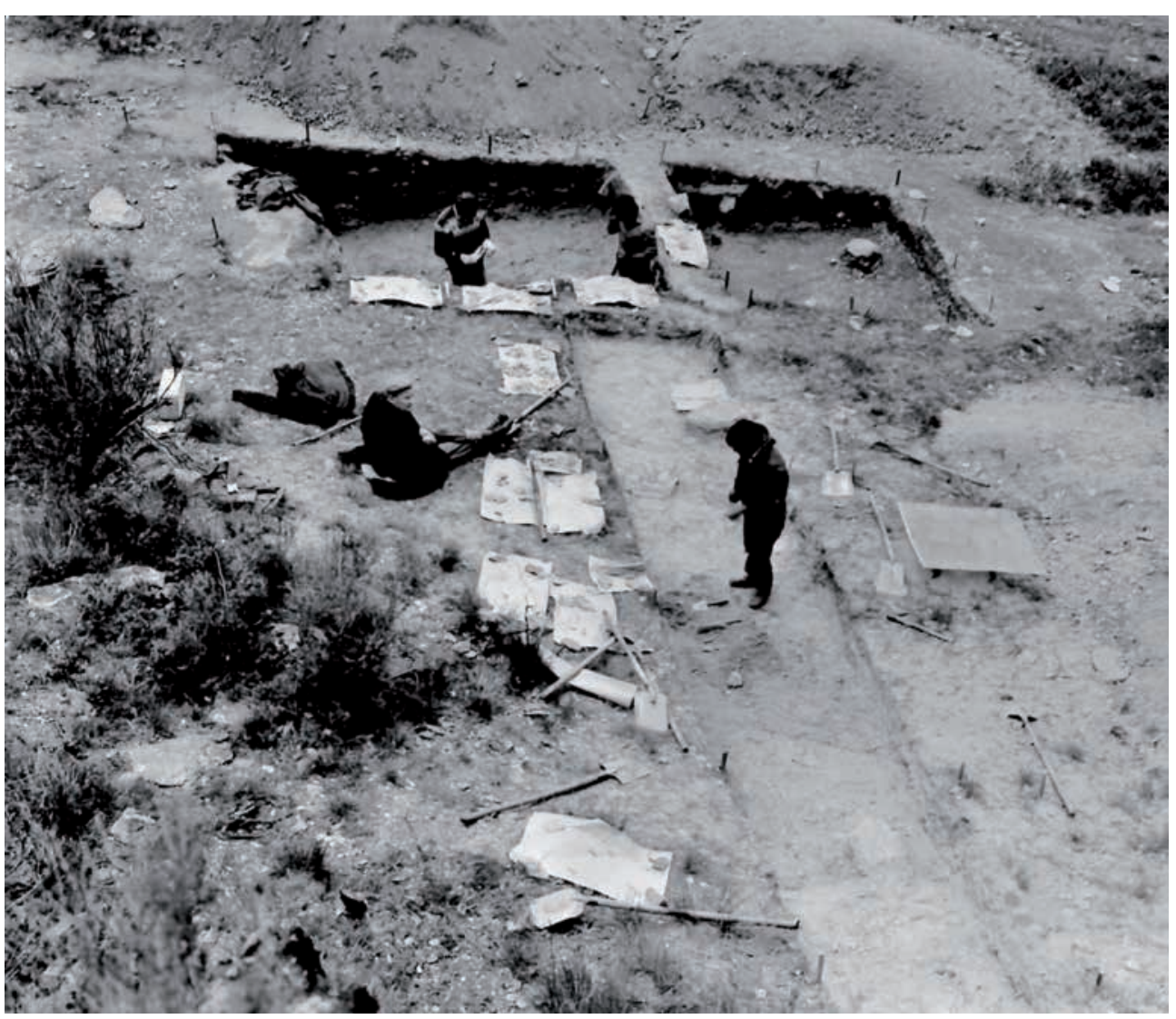

Рис. 4. Палеолитическая стоянка Кара-Бом. На переднем плане сидит А. П. Окладников. 1980 г. Фото А. Глотова

Fig. 4. Paleolithic settlement Kara-Bom. In the foreground sits A. P. Okladnikov. 1980. Photo by A. Glotov

оставался И. В. Асеев. Мы заложили небольшой раскоп на памятнике Кара-Тенеш и на значительной глубине выявили культурный слой с артефактами и остеологическим материалом. Влажная, мягкая земля не успела просохнуть после зимы, поэтому мы копали с удовольствием и быстро справились с поставленной задачей. АП вернулся через неделю, а утром мы собрались и поехали на раскопки новой стоянки, которую случайно обнаружил Алексей Павлович в ходе разведок. Он рассказал, что когда местные жители прокладывали дорогу, бульдозер разрушил верхнюю часть края стоянки и обнажил куль- турные слои с каменными орудиями из кремнистой породы черного цвета. Теперь мы должны спасти памятник археологии, пока его совсем не уничтожат. Должен заметить, Алексей Павлович не любил засиживаться на одном месте, он постоянно был в движении. Если мы в пути где-то останавливались на «перекур», он успевал пройтись, осмотреть окрестности и обязательно что-то находил. Хоть в этом мы старались подражать ему, но безуспешно.

Новая стоянка каменного века находилась в Онгудайском районе Алтайского края, недалеко от с. Ело и назвали ее Кара-Бом (Черный при- 
Таймагамбетов Ж. Память о моем учителе - Алексее Павловиче Окладникове

жим) (рис. 5). Вот здесь Алексей Павлович задержался чуть дольше, чем на других памятниках. Лагерь разбили рядом, на открытой местности. В первую очередь, мы занялись сбором подъемного материала, а затем был заложен раскоп. Целый день мы, А. К. Конопацкий, В. Т. Петрин, Ю. П. Холюшкин и я, копали стоянку, отлучались только на обед, приготовленный Борисом Абрамовым на костре, и снова за работу. Иногда на помощь приходили А. Глотов и В. Мыльников, хотя перед ними стояла иная задача.

Некоторое время рядом с нами находился отряд под руководством
А. П. Погожевой, который копал небольшой могильник эпохи раннего железа. Палатка АП всегда была в отдалении от основных, так как молодые ребята - Володя Мыльников, Саша Глотов, Ира Кедрова, Петр Лабецкий и водители всегда по вечерам слушали песни Владимира Высоцкого на магнитофоне с записью на кассете с лентой. Часто ее «заедало», лента рвалась, ребята ее склеивали и вновь разносился хриплый голос барда. Алексею Павловичу не нравился его голос и его песни. Я, Трофимыч, Юра Холюшкин, Николай Оводов немного держались в сторонке, иногда пристраивались к костру. Зачастую

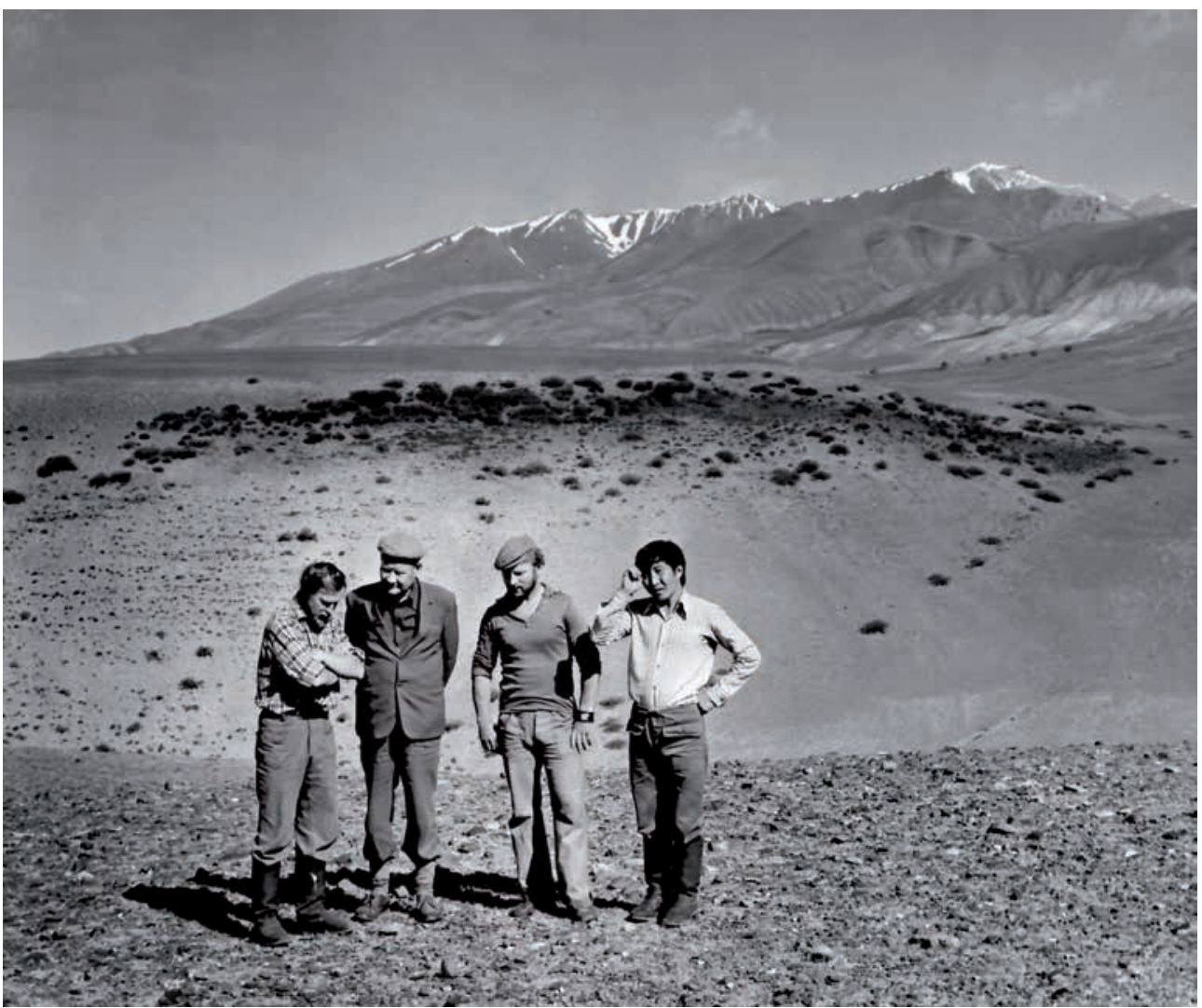

Рис. 5. Стоянка-мастерская Бигдон. Слева направо: В. Кубарев, А. П. Окладников, водитель Сама и Ж. Таймагамбетов. 1980 г. Фото из архива Ж. Таймагамбетова

Fig. 5. Settlement-workshop Bigdon. From left to right: V. Kubarev, A. P. Okladnikov, driver Sasha and Zh. Taimagambetov. 1980. Photo from the archive of Zh. Taimagambetov 
и Алексей Павлович любил сидеть у костра. В такие моменты была полная тишина, так как АП рассказывал нам истории из своей жизни, об археологии и древних культурах прошлого, новых открытиях. И я уносился в неведомые дали далекого времени, к загадочным людям Кара-Бома, которые жили в то время и оставили большое количество артефактов. Я мысленно, как бы со стороны, наблюдал за ними и вновь возвращался к АП. Он умел привлечь внимание, и мы с удовольствием слушали его рассказы под звездным небом Алтая. В какой-то момент, что-то вспомнив, АП вставал и, пожелав спокойной ночи, уходил в свою палатку. Там он, зажигая свечи, работал над рукописью книги или статьи, а перед сном, в тихой ночи, до нас доносилась негромкая музыка. Алексей Павлович любил классическую музыку. Рано утром он уже работал, сидел на стульчике у палатки, что-то читал или делал пометки в полевой книжке.

Однажды вечером как-то получилось что мы, молодые, сидя у костра, устроили дружескую борьбу с Александром Кирилловичем. Болельщики разделились на два лагеря. Алексей Павлович был на моей стороне и «болел» за меня. Со стороны это выглядело смешно. Огромный Александр Киррилович и я, маленький, на голову ниже его. Мне показалось, он и не пытался со мной бороться. Когда я поднял его на плечо, он от смеха не мог даже сопротивляться и я, воспользовавшись моментом, положил его на землю. В это время АП удовлетворенно хлопая в ладоши, скандировал: «Так ему и надо, агрессору...». Ирина Кедрова была на стороне Александра Кирриловича: «Конечно, Жакен поборет, потому что он бегает каждое утро, занимается спортом...». Действительно, каждое утро, пока все спали, я делал пробежку, но далеко от лагеря не отходил, так как за каждым деревом мне мерещились медведи.

В один из вечеров АП сказал мне: «Завтра, Жакенчик, вставайте пораньше, соберите все необходимое, мы поедем на несколько дней в КошАгачский район для встречи с казахами, посмотрите как они живут. Вы же казах, а не знаете родной язык, поговорите с ними, пообщайтесь, ведь в будущем надо знать свой язык..., а по дороге произведем разведочные работы по поиску новых памятников археологии». К моему стыду, действительно я не знал родного языка. Ведь с 5-го класса я рос в интернате, да и казахов было в селе мало. Как был мудр и прав Алексей Павлович. Сейчас у меня нет проблем с родным языком.

И вот мы в пути. За рулем экспедиционной автомашины водитель по имени Саша Крицын, спокойный, но профессионал своего дела. Он доказал это по преодолению сложной дороги и серпантина Чуйского тракта. Никогда не забуду день, как после обеда мы остановились в долине р. Чуи, недоезжая нескольких километров до районного центра Кош-Агач. Здесь нас встретил сотрудник метеостанции и, в то же время, любитель археологии Владимир Кубарев. Впоследствии, благодаря Алексею Павловичу, он защитил докторскую диссертацию и стал известным ученым-археологом. Он и показал нам обнаруженные им петроглифы на невысокой гряде Мешельдык, несколько рунических надписей в местечке Жалгыз-Тобо, во время осмотра которой на нас налетела огромная туча мелкой мошки. 
Таймагамбетов Ж. Память о моем учителе - Алексее Павловиче Окладникове

От нее невозможно было спрятаться, она пробиралась в уши, нос, глаза и сквозь волосы в голову. Я думал лишь об одном, как скорее убраться отсюда и забраться в машину. АП спокойно, как ни в чем не бывало, продолжал внимательно рассматривать рисунки. Вот это выдержка и терпение! В эти минуты он забывал обо всем, для него главным была работа. Глядя на него, мы тоже вынуждены были терпеть неудобства. Да и он не давал нам расслабиться. Алексей Павлович отнес надписи к древнетюркскому периоду и посоветовал В. Кубареву обратиться к тюркологам Института В. М. Наделяеву и Е. Д. Убрятовой. Он мгновенно решал многие вопросы, не откладывая на завтра.

Мы побывали в юрте у казахов. Убранство было скромное. Посередине юрты был подвешен казан с молоком. Самого хозяина-пастуха не было дома и, выпив горячего молока, поговорив с хозяйкой, мы покинули жилище. Мне показалось, что если бы был хозяин, то АП задержался бы. В дальнейшем не раз убеждался, что ему доставляло удовольствие общаться с простыми людьми. Ведь зачастую пастухи и местное население были источниками информации о памятниках археологии, о пещерах, о выходах сырья, рисунках на скалах, каменных изваяниях, курганах и т.д.

После этого Владимир Кубарев показал Алексею Павловичу и нам стоянку-мастерскую палеолитического времени на небольших возвышенностях в местечке Бигдон (рис. 5), у подножья Курайского хребта. Меня поразило, что многочисленные леваллуазские нуклеусы, каменные орудия, остроконечники, скребла и отщепы располагаются прямо на поверхности и на большой площади. Алексей Павлович говорил, что в Монголии такое явление часто встречается и датировал обнаруженный памятник мустьерским временем. Позже, в Казахстане, наша совместная экспедиция с российскими коллегами во главе с академиком А. П. Деревянко обнаружила десятки подобных стоянок-мастерских человека эпохи палеолита.

Возвратившись через несколько дней в лагерь, мы продолжили раскопки на стоянке Кара-Бом. Каждый день преподносил сюрпризы в виде уникальных орудий, площадок для обработки камня. Работать на Кара-Боме было интересно. В минуты перерыва мы ходили по склону и находили артефакты. Все эти находки показывали и обсуждали с АП. Он мог часами рассказывать, но в какоето время останавливался, хлопал ладонями по коленям и говорил: «За работу!».

Однажды вечером, оставшись вдвоем с Александром Кирриловичем у костра, он передал мне предложение Алексея Павловича поступить к нему в аспирантуру. У меня была годичная стажировка, на три года наше руководство поскупилось. Из них три месяца ушло на обустройство, переезд Института и только два месяца в полевых условиях я вплотную вникаю и занимаюсь археологией. Я и не думал об аспирантуре. «Я не готов поступать...», - ответил я. Естественно, Александр Киррилович передал мои слова АП.

Нас увлекли раскопки памятника Кара-Бом, каждый поделенный между нами квадрат ежечасно преподносил все новое. Александр Киррилович тщательно заносил карандашом на планшет-миллиметровку находки каждого квадрата, допол- 
нительно делая зарисовки камней, остатки очага. Я, выросший в селе, не избегал тяжелой работы, Трофимыч уже имел большой опыт в полевых условиях, поэтому мы понимали друг друга с полуслова. Мы выравнивали и производили зачистку стен, копали и носили ведра с землей в отвалы, делали все, что должен уметь археолог. Для меня это была хорошая практика. Алексей Павлович сидел на стульчике и внимательно следил за ходом работ, за нами, как мы работаем. Мы с Трофимычем, да и другие ребята, иногда подходили к нему и показывали уникальные экземпляры находок. В эти минуты он преображался, глаза светились искоркой, и он сразу начинал рассказывать о леваллуазской технологии расщепления. Он мог часами говорить, но обрывал свою речь и говорил: «Идите работать». Алексей Павлович постоянно думал о работе.

В минуты отдыха Юрий Холюшкин рассказывал о палеолите и об археологах Узбекистана, о Самаркандской стоянке, так как он оттуда родом и успел поработать там. Трофимыч говорил о палеолите Урала, о стоянке Могочино, которую он раскапывал и Игнатиевской пещере, которую только начал исследовать. А я все слушал их рассказы.

Однажды вечером у костра, уже в присутствии Айны Петровны Погожевой и Трофимыча, Александр Киррилович повторил предложение АП о моем поступлении в аспирантуру. И когда я сказал: «Мне еще рано в аспирантуру», он тихо сказал: «Жакен Кожахметович, надо, ведь Алексей Павлович не каждому предлагает поступить к нему в аспирантуру. Другие бегают за ним годами или за них просят руководители Институтов, вузов. А тут сам академик предлага- ет, а ты отказываешься. Он знает, что говорит...». Айна Петровна, которую я очень уважал, поддержала Александра Кирриловича и предложение от АП «не отказываться». Ну а Трофимыч, который уже был в заочной аспирантуре у АП, просто сказал: «Я бы не отказался, соглашайся». После всего этого я дал свое согласие. Это было в июле 1980 года.

На следующий день АП собирался в Новосибирск и сказал мне срочно собираться и ехать вместе, далее лететь в Алма-Ату. Я должен подготовить и сдать до 1 августа необходимые документы для поступления в очную аспирантуру. Для меня это было неожиданно, не думал, что это будет так скоро. Мне не хотелось покидать друзей, привычный ритм работы на Кара-Боме. В этом отношении, Алексей Павлович мгновенно принимал решение и был очень мобильным.

После завтрака, наскоро закидав вещи в рюкзак, попрощавшись с ребятами, я поехал с АП на машине, уже на «Волге», за рулем которой был прекрасный человек - Анатолий Борисов. По дороге, делая остановку, Алексей Павлович посылал меня сбегать на ту или иную горку и внимательно посмотреть обнажение террасы, обратить внимание на наличие каменных изделий и т.д. Сам же уходил по другую сторону дороги. И здесь он не терял время, производил разведочные работы. Мы побывали на стоянке Улалинка, которую открыл АП, и он рассказал о древних артефактах из кварцита, обнаруженных им в погребенном виде. Эти орудия он относил к позднему плиоцену и предварительно датировал возрастом более 1 миллиона лет назад. Но есть и скептики, о которых он говорил. А 
Таймагамбетов Ж. Память о моем учителе - Алексее Павловиче Окладникове

потом ссылался на подтверждение данными естественнонаучных наук и рассказывал о палеомагнитном методе. АП показал огромный камень со следами раскалывания, который находился рядом и рассказывал, как его раскалывали с помощью огня. Человек щедрой души, добрый, скромный и обаятельный в жизни Алексей Павлович широко делился своими энциклопедическими знаниями не только со мной, но и со всеми, кто его окружал.

Уже в Алма-Ате я рассказывал всем в отделе археологии, кто был свободен от экспедиции, что меня сам А. П. Окладников пригласил поступить в аспирантуру. Мало кто верил мне, я это чувствовал, многие решили, что я из «блатных», т.е. сын высокопоставленных чиновников. Если бы так. Мало кто знал, что четыре года я пытался поступить в университет, работал на стройке и жил в общежитии «спецконтингента» под постоянным оком дежурных милиционеров из комендатуры. В то время, чтобы поступить в аспирантуру, нужно было поработать, показать себя в стремлении к науке или просто иметь хорошую поддержку в руководстве, а я, благодаря Алексею Павловичу, даже не окончив годичную стажировку, получил такой шанс.

Я успел вернуться в Новосибирск и вовремя подал документы в аспирантуру ИИФиФ СО АН СССР. Теперь нужно было готовиться к экзаменам. Сдать экзамен по философии и иностранному языку. Нас было двое на одно место. Мы познакомились с коллегой-археологом, это был Саша Константинов из Читы. Спокойный, добрый и рассудительный человек. Мы оба сдали в августе-сентябре экзамены положительно и стали ждать зачисления, которое затянулось надолго. По совокупности полученных оценок на экзамене у меня было на один балл больше, чем у Саши. Но у Саши был опыт полевых работ, чего не было у меня.

Все ждали возвращения Алексея Павловича из Дальнего Востока, где он находился в археоэтнографической экспедиции. Я поражаюсь, 6-7 месяцев находиться в полевых условиях. Это сейчас для меня нормальное явление, а тогда для меня это было как-то непривычным.

И вот 1 декабря 1980 г. вышел приказ по Институту истории, филологии и философии СО АН СССР о зачислении меня в очную аспирантуру сроком на три года и моим руководителем назначен А. П. Окладников. Радовались все мои новые друзья, в том числе и Саша Константинов. Несмотря на итоги зачисления, мы остались друзьями и сегодня переписываемся, делимся новостями в археологии.

Казалось, что теперь я буду часто видеться с научным руководителем, но нет, Алексей Павлович был неуловим, постоянно занят, его приглашали на различные мероприятия, встречи, выступать на ТВ и радио и т.д. Он всегда был в окружении людей.

Как научный руководитель, Алексей Павлович дал мне тему кандидатской диссертации «Проблема леваллуа-мустье Казахстана». Я работал над ней и в то же время Трофимыч загрузил меня камеральной обработкой каменных орудий из памятников Алтая. За рабочий день нужно было вымыть артефакты, просушить, нанести белой краской светлый фон, дать ей высохнуть, затем нанести шифр тушью, дать просохнуть, покрыть лаком, чтобы шифр сохранил- 
ся, упаковать и поместить в коробки. Не меньше 350 артефактов в день, такую норму установил Трофимыч. И так каждый день. С каждым днем я перевыполнял норму. Бывали дни, когда я шифровал до полутора тысяч артефактов. Я приступал к работе с раннего утра и часто засиживался на чердаке до 12 ночи - лучше было работать, когда никого не было. Благо, что общежитие на Ученых, 8, находилось в 10 минутах ходьбы. Кстати, Алексей Павлович через Управление делами СО АН СССР добился, чтобы мне выделили отдельную комнату в общежитии. Несмотря на сложности того времени, комнату мне нашли, поэтому у меня не было проблем, когда и в какое время приходить ночевать.

В одну из таких ночей, когда я сидел и шифровал камни, открывается дверь и заходит Алексей Павлович с водителем Анатолием Борисовым. Я вскочил от неожиданности. Поздоровавшись, он спросил: «Чем Вы, Жакенчик тут занимаетесь?». «Шифрую материалы, Алексей Павлович...». Он сел, посмотрел на разложенные коллекции и сказал: «Еду я мимо и вижу, что горит свет в одном из окон чердачного помещения. Думаю, кто там оставил не выключенным свет, не дай бог пожар случится, или может ктото из сотрудников загулял до ночи, решил посмотреть, а это Вы работаете... Ну, молодец, но надо отдохнуть. Давайте я вас подвезу на машине куда надо, какой академик еще вас подвезет». Я отказался, сказал, что мне идти здесь близко, завершу и пойду, заодно подышу воздухом. Алексей Павлович обнял меня, тут же прошагал к столу Александра Кирриловича и, распечатав коробку с книгами, вынул одну из них в красной обложке «Открытие Сибири» и размашистым почерком написал «Дорогому Жакену Кожахметовичу за усердие в науках!», поставил подпись и вручил мне. До сегодняшнего дня она находится на видном месте в моей библиотеке, я храню и берегу ее.

Учеба, работа, пролетела зима. Как аспирант я посещал занятия по философии и иностранному языку. Помню, тема моей зачетной работы по философии звучала так «Гносеологические проблемы магического происхождения искусства и графики в палеолите», за что я получил высокую оценку преподавателя. А по иностранному языку я переводил с немецкого на русский язык книгу Г. Кюна «Искусство ледникового периода» и тоже получил положительную оценку.

С Алексеем Павловичем я встречался только по мере необходимости, докладывал о трудностях в сборе информации по теме диссертации, так как вопросы леваллуа были для меня сложными, и он обещал чтонибудь придумать, найти правильное решение.

В Институте я часто общался со многим корифеями археологии, этнографии, палеонтологии, истории, филологии и философии - В. И. Молодиным, Р. С. Васильевским, В. Е. Ларичевым, В. Е. Медведевым, Ю. С. Худяковым, И. Н. Гемуевым, Н. Д. Оводовым, И. В. Асеевым, В. В. Алексеевым, В. И. Ламиным, познакомился с другими археологами Алтая, Сибири и Дальнего Востока - Ю. Ф. Кирюшиным, Г. И. Медведевым, Н. И. Дроздовым, А. И. Мартыновым, В. В. Бобровым, И. И. Кирилловым, М. В. Константиновым, Д. Л. Бродянским, из Японии Харуо Ойи и Кимура Хидеаки и многими другими. Все они всегда оказывали 
мне помощь и давали ценные советы. Я не забуду своих друзей - Ю. Холюшкина, П. Лабецкого, В. Эрлиха, Ю. Гричана, Д. Березина, С. Глинского, М. Бурилова, А. Соловьева, Н. Полосьмак, И. Кедрову, О. Швец, В. Мыльникова, С. Глотова, Б. Абрамова и многих других, готовых помочь мне в любую минуту. Я быстро адаптировался среди них.

Однажды Алексей Павлович пригласил меня к себе домой и в спокойной обстановке мы говорили о моей работе и планах на будущее. Тогда он и предложил поменять тему моей будущей кандидатской работы на «Периодизацию палеолита Южного Казахстана». Затем он предложил мне поехать в Казахстан на лето и поработать в сопредельной Горному Алтаю территории, т.е. в Восточном Казахстане. Я с радостью согласился, тем более в Казахстане возобновила работы Шульбинская археологическая экспедиция в зоне будущего затопления Шульбинской ГЭС. Получив необходимые сопроводительные документы и напутствие от Алексея Павловича, я приехал в Алма-Ату, где меня назначили начальником палеолитического отряда. Поработав четыре месяца в экспедиции, я обнаружил несколько прекрасных памятников палеолита, в том числе и стратифицированную стоянку Шульбинка. По возможности, я звонил из почтового отделения и ставил в известность своего научного руководителя о своих открытиях, знакомил с ходом работ и получал ценные советы. По завершению экспедиции, в конце сентября, в Алма-Ате я купил билет на самолет, позвонил Алексею Павловичу, чтобы сообщить о своем скором прибытии в Новосибирск.
Алексей Павлович попросил сдать билет обратно и задержаться в Алма-Ате по причине того, что он сам завтра вылетает в Алма-Ату для участия в международной конференции, посвященной 250-летию добровольного вхождения Казахстана в состав России. Мы договорились, что я встречу его в аэропорту.

На следующий день, после обеда, я был в зале ожидания аэропорта. Здесь я встретил вице-президента Академии наук КазССР академика Б. А. Тулепбаева, директора Института истории, археологии и этнографии им. Ч. Ч. Валиханова, академика А. Н. Нусупбекова и его заместителя члена-корреспондента Г. Ф. Дахшлейгера. Поздоровавшись с ними, один из них поинтересовался, что я тут делаю. Я ответил, что приехал встретить своего научного руководителя, академика А. П. Окладникова из Новосибирска. Не буду называть фамилию, но он довольно резко сказал: «Тебе здесь делать нечего, уезжай отсюда, мы сами встретим его...». Я вынужден был подчиниться, было обидно, что не смогу встретить Алексея Павловича. Я сравнивал его с нашим академиком, который мне сказал покинуть здание аэропорта. Алексей Павлович никогда не позволил бы себе так разговаривать. Он всегда был со всеми на Вы. С такими мыслями я подошел к ограждению взлетной полосы, чтобы хотя бы издалека увидеть дорогого мне АП. Наконец приземлился самолет, подали трап и начали спускаться пассажиры. Я видел, как подъехали две черные автомашины и из нее вышли мои «знакомые» из зала ожидания. По трапу спускался Алексей Павлович в коричневом костюме, а рядом с ним Александр Кирилович. После рукопожатий он сели в маши- 
ны. Мне хотелось крикнуть им, что я здесь, но было далеко, да и неуместно кричать, кругом люди.

Делать нечего, я пошел на остановку автобуса. И надо же, мимо меня проезжают автомашины и через некоторое время они останавливаются и из одной из них выходят Алексей Павлович и Александр Киррилович. Алексей Павлович, раскинув руки для объятий, идет ко мне. Я побежал навстречу, он обнял меня и так мы простояли некоторое время. Я был горд, Алексей Павлович и тут проявил человеческие качества, не проехал мимо. Как такое забыть? Он был интеллигентным и с высокой внутренней культурой, всегда заботился обо мне, о людях и относился с уважением ко всем. Люди на остановке с удивлением смотрели на нас, пожилой человек со звездой Героя обнимает молодого человека. Вынуждены были выйти из машины мои «знакомые». Нас окружили, а АП все приговаривал: «Вы знаете его, он мой аспирант и т.д. Вы еще услышите о нем...». Он радовался не меньше, чем я, все держал меня в объятиях. «Знакомые» улыбаясь, пожимали мне руки и торопили Алексея Павловича, что надо ехать и когда АП сказал мне сесть в машину, те вежливо ответили - «нет места». Алексей Павлович сказал им, чтобы сообщили мне, где их разместят. И только тогда, когда они сообщили мне адрес гостиницы, Алексей Павлович уехал. Я остался на остановке ждать автобус. Вспомнил когда-то сказанные слова Алексеем Павловичем: «Садитесь, я подвезу, какой еще академик Вам предложит сесть в машину?». Прошли обиды, главное, я встретился с Алексеем Павловичем. Оказывается, благодаря Александру Кирриловичу, который увидел меня в окно, маши138 ны сделали вынужденную остановку. Приехав в гостиницу, я увидел, что Алексея Павловича уже увозят кудато на ужин. Тем не менее, он нашел время и взял у меня на всякий случай мой адрес, где я проживаю.

На следующий день торжественное заседание проходило в здании оперного театра. Приехали со всего союза известные ученые. Я запомнил только фамилии академиков П. Н. Федосеева, И. И. Минца. Алексей Павлович выступил на пленарном заседании. У него не было подготовленных официальных докладов. Он говорил с трибуны о дружественных связях Казахстана и России, ведущих начало с древних времен. Акцентировал внимание на истории Сибири, жизни и подвиге Ермака, ссылаясь на новые, неизвестные факты, новые документы, и в заключение пригласил всех на празднование 300-летия присоединения Сибири к России. Всем запомнились его слова: «В Казахстане много исторических памятников, но не хватает одного - это памятник Абулхаир-хану, который обратился к императрице Анне Иоанновне с просьбой о принятии в подданство России».

После выступления его пригласили в фойе дать интервью ТВ и радио, газеты. Его буквально разрывали на части, то на встречу с учеными, то на телевидение и т.д. Алексей Павлович никому не отказывал, он шел за всеми, но Александр Киррилович умел вовремя пресекать и отказывать некоторым. И даже в такие суматошные минуты Алексей Павлович не забывал обо мне и в одном из интервью сказал: «...У меня много учеников. Самый юный - казах Жакен Таймагамбетов. Он с такой энергией, самоотверженно работал на Алтае, 
участвовал в раскопках, нашел интересные памятники древней культуры. Приятно знать, что есть такие ученики, как Жакен...» [Соловьева, 1983]. Мне и сегодня дороги эти слова, а в то время его мнение, услышанное многими нашими учеными, для меня было очень сильной поддержкой.

О встрече с Алексеем Павловичем не было и речи. Его опять увезли на какое-то мероприятие. Но хорошо, что рядом всегда был бдительный Александр Киррилович, который не давал «растерзать» его.

Закончились торжественные дни. Было дождливое ранее утро. Суббота. Я лежал в съемной квартире и вдруг звонок в дверь. Вскакиваю, открываю дверь, а на пороге в сером плаще и шляпе на голове стоит сияющий Алексей Павлович с большой картонной коробкой, рядом с ним Александр Киррилович. Вот не ожидал, я ищу встречи с ним, а он сам пришел. Спросив разрешения пройти в дом, он с ходу распаковал коробку, полную ароматных, знаменитых яблок «Апорт» со словами: «Кто-то вчера мне принес, в знак благодарности, а зачем мне так много, вот вам и привез, ешьте». Я засуетился, дома ничего съестного не было, сказал, что сбегаю в магазин. Он остановил меня: «Мы позавтракали, нам бы только чайку». В ту же минуту я быстро почистил и пожарил картошку на сковороде, так и подал к столу. Оказывается, несмотря на запрет жареного, он любил картошку. Здесь нам никто не мешал, мы за чаем обо всем поговорили, о работе, экспедиции, семье. Я показал ему находки со стоянки Шульбинка. Его внимание привлекло плоское скребловидное орудие размером больше ладони из светлого крем- ния, обработанное мелкой ретушью со спинки. Он долго рассматривал его, вертел в руках и приговаривал: «...интересно, интересно...». Потом посоветовал написать письмо его давнему другу профессору Мюллербеку из Германии и проконсультироваться с ним по поводу аналогий подобным находкам.

Потом он спросил, куда мы могли бы поехать, чтобы скоротать время. Я решил показать Медео, но он сказал, что был там. Тогда я предложил поехать к мемориалу народного акына Джамбула Джабаева, который не дожил несколько месяцев до своего столетия. Помните его стихи, написанные в годы войны «Ленинградцы, дети мои! Ленинградцы, гордость моя!...». Алексей Павлович с радостью согласился, хотя мемориал находился в 45 км от Алма-Аты. Нужно было заехать в гостиницу «Казахстан», где проживала его личный врач из Новосибирска Ида Тимофеевна и что-то у нее взять, а заодно и пригласить поехать с нами. У входа стоял академик из Москвы Исаак Израилевич Минц. Алексей Павлович предложил ему поехать с нами к памятнику Джамбула. Тот вежливо отказался, но расспросил, где он находится. Когда уже отъехали от гостиницы, АП сказал: «Он не зря спросил, приедет он, но один... вот посмотрите, помяните мое слово...». Дождь понемногу стихал и, когда мы приехали к мемориалу, прекратился. Осмотрев памятник, сделав несколько снимков на память (рис. 6, 7) и возвращаясь в город, встретили машину, закрепленную за академиком И. И. Минцем. Он в гордом одиночестве восседал в машине. Алексей Павлович помахал ему рукой из окна и сидел, улыбался, видимо, убежденный в своей правоте. 


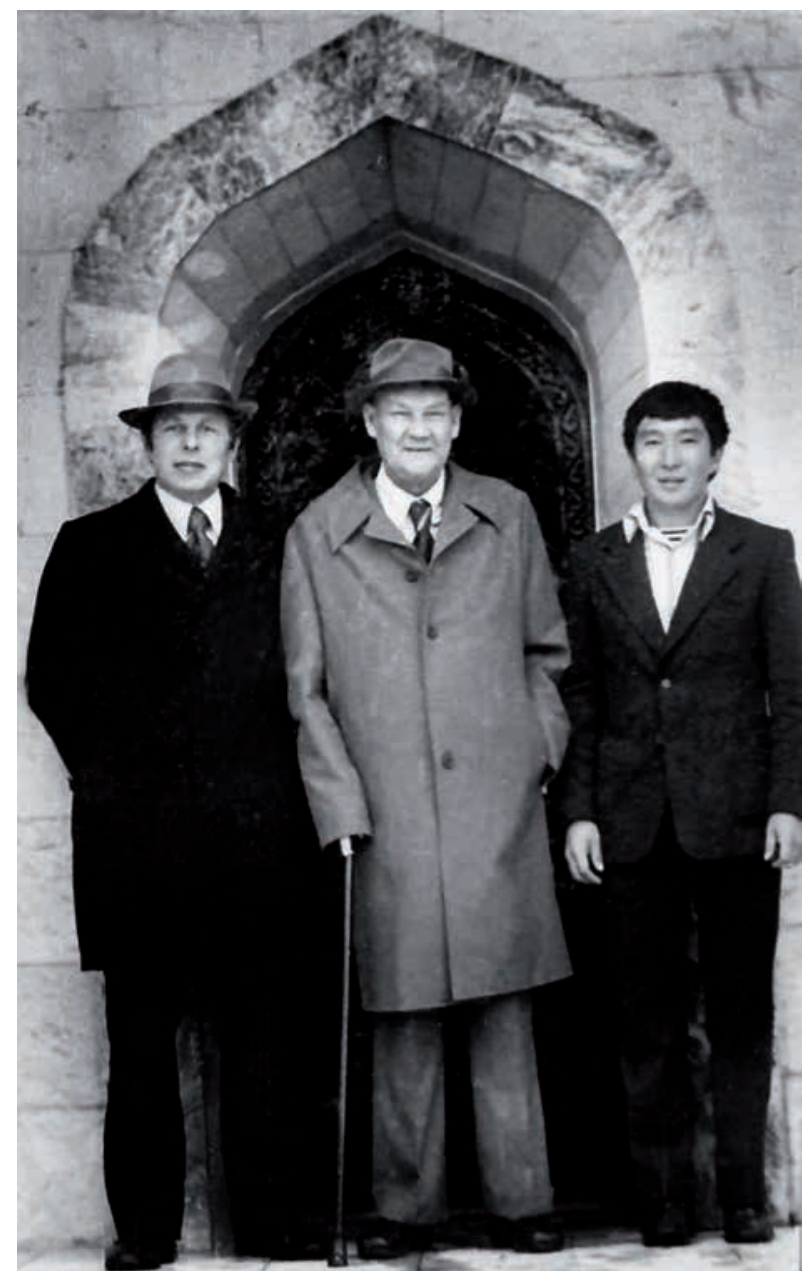

Рис. б. А. П. Окладников, А. К. Конопачкий, Ж. К. Таймагамбетов у мемориала Джамбула Джабаева. 1981 г. Фото из архива Ж. Таймагамбетова

Fig. 6. A. P. Okladnikov, A. K. Konopatskiy, Zh. K. Taimagambetov at the memorial of Jambyl Jabayev. 1981.

Photo from the archive of $\mathrm{Zh}$. Taimagambetov
А. М. Кунаевым по поводу меня. И тот пообещал, что после окончания аспирантуры мне предоставит жилье в Алма-Ате. Я радовался, будто уже получил квартиру. Даже в такие моменты, когда все позволяют себе немного расслабиться, он заботился и думал обо мне. Я проводил дорогих гостей в аэропорт и далее на посадку в самолет. Договорились, что я приеду через несколько дней, как завершу дела в Алма-Ате.

После приезда в Новосибирск Алексей Павлович оформил мне командировку в Волгоград, чтобы ознакомиться с коллекциями Сталинградской стоянки, а заодно перевезти семью в Академгородок. Зная, что моя супруга филолог по образованию, он думал подыскать ей работу, а затем подготовить ее для поступления в аспирантуру. Это было в октябре. Попрощавшись, я улетел в Волгоград. Ничто не предвещало, что это была наша последняя встреча. Больше я его не видел.

Я перевез жену и дочь
Вечером был торжественный прощальный ужин для гостей.

Утром, 3 октября, Алексей Павлович, Александр Киррилович и Ида Тимофеевна улетали в Новосибирск. Я купил цветы, белые хризантемы, поздравил Алексея Павловича с днем рождения. По дороге он сказал мне, что вчера за ужином разговаривал с Президентом Академии наук из Волгограда в Новосибирск и иногда, прогуливаясь с ними мимо коттеджа, где проживал Алексей Павлович, надеялся встретить его. Я знал, что он в Москве, а вдруг приехал и я увижу его на улице. Но он не приезжал. Находясь в Москве, в больнице, он по телефону передал Александру Кирриловичу как должна выглядеть структура моей диссертационной ра- 


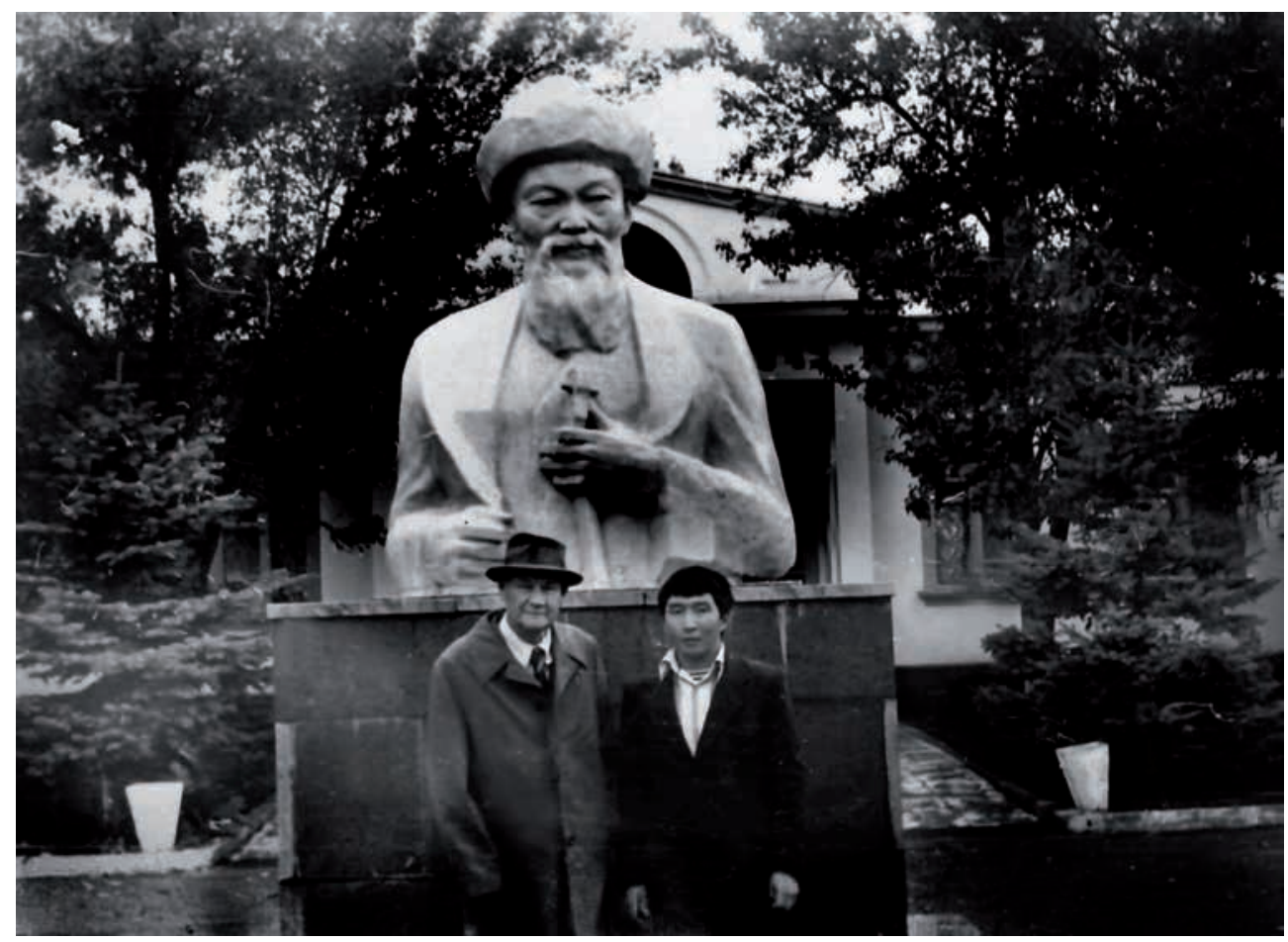

Рис. 7. А. П. Окладников и Ж. К. Таймагамбетов у памятника Джамбулу Джабаеву. 1981 г. Фото из архива Ж. Таймагамбетова

Fig. 7. A. P. Okladnikov and Zh.K. Taimagambetov at the monument to Jambyl Jabayev. 1981. Photo from the archive of Zh. Taimagambetov

боты из-за измененной темы. Даже в такие минуты Алексей Павлович думал о работе, не забывал обо мне.

В общежитии мы часто проводили время вместе с Трофимычем и желали только одного, чтобы АП скорее выздоровел и приехал в Институт. Но однажды, а это было 18 ноября, Александр Кириллович сообщил скорбную весть. Алексей Павлович покинул нас.

Мы, археологи, начали готовить место на кладбище, под березой, на которую указал сам Алексей Павлович. Был сильный мороз, мы копали мерзлую землю, тщательно зачищая стенки, как будто на раскопе, чтобы не видно было следов от лопаты. У нас было два дня времени. Алексея Павловича должны были доставить самолетом из Москвы но- чью 20 ноября. Во время перерыва к нам с плачем подошла незнакомая женщина и попросила помочь завершить начатую могильную яму. Скоро должны были привезти гроб с ее родственницей, а ответственные люди за подготовку могилы исчезли куда-то. Она была в безвыходном положении и в отчаянии. Мы не могли отказать ей и с согласия коллег, вдвоем с Трофимычем, успели докопать могилу до того, как привезли покойницу. А затем и подготовили место для Алексея Павловича.

В ночь на 21 ноября мы были в аэропорту, помогали выгрузить из самолета тело АП и привезти его на автомашине в Академгородок.

С утра было прощание с Алексеем Павловичем. Народу было мно- 
го. Выступал президент СО АН СССР В. А. Коптюг и многие общественные и партийные деятели, соратники, друзья. Александр Кириллович все время стоял у изголовья Алексея Павловича. Мы, археологи, несли гроб, поместили его на катафалк и колонна из многочисленных автомашин двинулась на кладбище. После был воинский салют. Разошлись все, кто пришел проститься с Алексеем Павловичем. Остались у могилы лишь несколько сотрудников из Института, которых не пугал ни мороз, ни быстро надвигающая ночь. Пусто было на душе и одиноко.

Теперь мы втроем, Александр Кириллович, Трофимыч и я, часто были вместе. Уход Алексея Павловича сблизил нас. Однажды Александр Кириллович, когда был у меня в гостях вместе с Трофимычем, подарил мне книгу «Открытие Сибири» с подписью: «Дорогому Жакену Таймагамбетову на память о нашем общем учителе, удивительном человеке, Алексее Павловиче Окладникове, авторе этой увлекательной и интересной книги. 10 октября 1982 г., г. Новосибирск». Это было второе издание книги, подаренной в свое время мне Алексеем Павловичем, но отличие было только в том, что она была в синей обложке. Эти две книги дороги мне, потому что одна напоминает о моем учителе, а вторая о моем добром и надежном друге Александре Кирилловиче Конопацком.

Директором Института был назначен ученик Алексея Павловича, молодой и опытный археолог, прекрасный организатор науки, членкорреспондент (в звании академика с 1987 г.) Академии наук СССР Анатолий Пантелеевич Деревянко, который достойно и долгие годы руководит прекрасным коллективом. Начиная с 1992 года и по настоящее время, он оказывает непрерывную и неоценимую помощь в исследовании палеолита Казахстана. Мы дружим. Дружба, заложенная Алексеем Павловичем и преемственность поколений, продолжается.

В срок и успешно я защитил диссертационную работу на соискание ученой степени кандидата исторических наук с указанием научными руководителями академика А. П. Окладникова и доктора исторических наук Р. С. Васильевского. Таковы были требования «Положения ВАК...».

Я благодарен судьбе за то, что она свела меня с Алексеем Павлови-

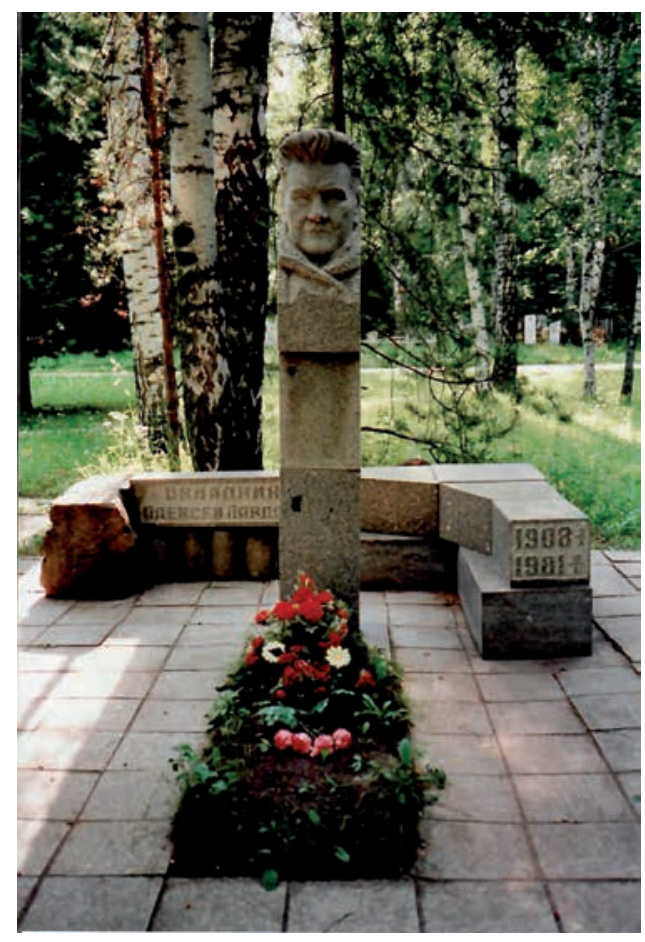

Рис. 8. Бюст А. П. Окладникова, установленный в г. Новосибирске. Фото из архива Ж. Таймагамбетова

Fig. 8. Bust of A. P. Okladnikov, installed in Novosibirsk. Photo from the archive of Zh. Taimagambetov 
чем Окладниковым в непростое для меня время. Я не забуду, какую он мне оказал помощь, поддержку и доверие, и я стараюсь равняться на таких людей, как он. Алексей Павлович был яркой личностью, отзывчивым, добрым человеком, настоящим ученым (рис. 8). Он остался в многочисленных научных трудах и людях, в своих учениках, к которым принадлежу и я, последний аспирант академика $\mathrm{AH}$ СССР Алексея Павловича Окладникова.

Портрет Алексея Павловича со всеми заслуженными его наградами на пиджаке всегда висит у меня над рабочим столом. Мягкая и добрая улыбка на лице и мне кажется, что он жив, просто находится в длительной экспедиции...

\section{ЛИТЕРАТУРА}

1. Соловьева Г.Г. Загадка счастья. Алма-Ата: Жалын, 1983. 228 с.

\section{Сведения об авторе:}

Таймагамбетов Жакен - доктор исторических наук, профессор, членкорреспондент НАН РК, главный научный сотрудник, отдел археологии и этнографии, Национальный музей РК, заслуженный деятель Республики Казахстан (г. Нур-Султан, Казахстан); zhaken.taimagambetov@gmail.com

\section{ҰСТАЗЫМ АЛЕКСЕЙ ПАВЛОВИЧ ОКЛАДНИКОВ ТУРАЛЫ ЕСТЕЛІК}

\section{Ж. Таймағамбетов}

2020 жылдың ақпанында тура 40 жыл болыпты менің ең алғаш рет КСРО ҒА Сібір бөлімшесінің Тарих, филология және философия институтының, қазіргі өз алдына жеке РҒА СБ Археология және этнография институтының табалдырығын аттағаныма. Сол жылы танысқан едім ірі ғалым, Сібір, Солтүстік, Орталық және Шығыс Азия халықтары археологиясы, этнографиясы мен тарихының аңыз адамы, Социалистік Еңбек Ері Алексей Палович Окладниковпен (1908-1981) (сур. 1). Анда-санда болсада біз бір жылдай араластық. Осының өзі менің өмірім мен есімде жарқын із қалдырды. Ал мына ессіз уақыт зымырап өтуде, менің ұстазымның мәңгілік экспедицияға кеткеніне де аттай 39 жыл өтіпті. Бірақ бәрі менің есімде, тіпті ұсақ-түйегіне дейін, біз кеше ғана қоштасқандаймыз. Алексей Павловичті, ең алдымен адам, ғалым ретінде ұмыту мүмкін емес. Бұның бәрі қалай басталды және болды... Шағын экскурс жасап, өткен оқиғаларды қалына келтіріп көрейін.

Түйін сөздер: археология, А.П. Окладников, РҒА СБ Археология және этнография институты, тас ғасыры, палеолит, естелік

\section{MEMORY OF MY TEACHER - ALEXEY P. OKLADNIKOV}

\section{Zh. Taimagambetov}

In February 2020 was exactly 40 years as I first crossed the threshold of the Institute of History, Philology and Philosophy of the Siberian Branch of the Academy of Sciences of the USSR, now independent Institute of Archaeology and Ethnography of the Siberian Branch of the Russian Academy of Sciences. Then I met an outstanding scientist, legend of archaeology, ethnography and history of the peoples of Siberia, North, Central and East Asia, 
Hero of Socialist Labor, Alexey P. Okladnikov (1908-1981) (fig. 1). A little over a year we contacted, albeit occasionally. However, it was enough for him to leave a bright mark in my life and memory for a long time. Crazy time is flying rapidly, and it has been 39 years since my teacher left forever, went on an eternal expedition. I remember everything about him, everything to the smallest detail, as if we had parted ways recently. Alexey P. Okladnikov is impossible to forget, first of all, as a person, as a scientist. How it all started and it was... I will try to make a small excursion and restore the events of the past.

Keywords: archaeology, A. P. Okladnikov, Institute of Archaeology and Ethnography of the Siberian Branch of the Russian Academy of Sciences, Stone Age, Paleolithic, memories

\section{REFERENCES}

1. Soloviyova, G. S. 1983. Zagadka schastiya: opyt filosofskogo razmyshleniya (The riddle of happiness: the experience of philosophical reflection). Alma-Ata: "Jalyn" Publ. (in Russian).

About the Author:

Taimagambetov Zhaken. Doctor of Historical Sciences, Professor, Corresponding Member of the National Academy of Sciences of the Republic of Kazakhstan, Chief Researcher, Department of Archeology and Ethnography, National Museum of the Republic of Kazakhstan, Honored Worker of the Republic of Kazakhstan, Nur-Sultan, Kazakhstan; zhaken.taimagambetov@gmail.com 